one-third of the total population of Saskatchewan birds and four-fifths of Regina's breeding bird population breed have bred in the Regina Waterfowl Park.

Acknowledgements: Thanks go to Vic Wadman, at the Regina Weather Office, for his much needed help in supplying the monthly weather summaries for the report of the nesting survey.

To Dwayne Harty and Keith Neufeld, who spent much of their time throughout May, June and July, helping me search the area for nesting species.

I am very grateful to Fred Lahrman and Lorne Scott, who gave suggestions on planning the survey and supplied the photographs.

I am very thankful to Margaret Belcher and Lorne Scott for proof- reading and editing the nesting survey report.

Most of all, I am especially indebted to Fred Bard, who introduced me to the Regina Waterfowl Park in 1972, and who originally suggested my doing a nesting survey. Throughout the past 5 years, $\mathrm{Mr}$. Bard has given continued encouragement and help to me in my interest in birds.

Editor's Note: Robyn Donison is 14 years old. Richard Sanderson's 1962 study involved only 45 hours of field work with Bill Fleming. Significant differences in some populations are apparent, e.g., the earlier study turned up 14 Pied-billed Grebe nests, 117 Coot nests and 12 Common Tern nests. Only 14 species were listed for 1962.

\title{
ADDITIONAL MANITOBA RECORDS OF SHORT-TAILED SHREW
}

\author{
WALTER KRIVDA, \\ Box 864, The Pas, Manitoba
}

Apparently the Short-tailed Shrew, Blarina brevicauda manitobensis Anders., is less scarce than is generally thought. I first collected this subspecies near The Pas, Manitoba, in 1951. My note in the Canadian FieldNaturalist (1951) gives the circumstances and data of the first specimen collected this far north in Manitoba.

In September, 1973, Mr. Phil Reader of Reader's Lake, 13 miles from The Pas, took a Short-tailed Shrew in a mouse trap. The specimen, in alcohol, is in the writer's collection. This specimen was taken near a house and out-buildings in a stand of jack pines in sandy woodland.

In February, 1975, the third local specimen for this area was found frozen to death in the writer's wood pile in town. This specimen was somewhat desiccated when found. It was put into alcohol and donated to the Manitoba Museum of Man and Nature, Winnipeg. When being made into a museum skin, the fur slipped from one hind quarter. The skull is in perfect condition.

As is so often the case with a new range extension, once the proper microhabitat has been discovered, it may prove to be more frequent than these few records over a 25-year period would indicate. 